\title{
Marine geophysical survey of the East Greenland shelf south of Angmagssalik
}

\section{Birger Larsen}

An offshore geophysical programme was carried out during the summer in order to conduct a seismic and magnetic reconnaissance of the shelf areas off southern Greenland. Due to technical problems, the survey was concentrated on the shelf off Sukkertoppen and in Julianehåb Bugt, West Greenland, and off East Greenland between $63^{\circ} \mathrm{N}$ and $65^{\circ} \mathrm{N}$. In all, the four-man team from the Geological Survey of Greenland, assisted by the crew of M/S Tycho Brahe, completed about $4500 \mathrm{~km}$ of seismic or magnetic profiles. Only the preliminary results of the survey of the shelf off East Greenland are presented here.

The equipment and interpretation technique are described by Denham (1974). Off East Greenland, positions were determined by Loran A.

The general morphology of the shelf off East Greenland was found to be similar to the conditions described by Sommerhoff (1973) to the south of $64^{\circ} \mathrm{N}$. The inner shelf topography is very irregular while the outer shelf, to the south-east, has a much smoother profile. In the western part of the shelf the deep extensions of Sermilik, Angmagssalik Fjord and Gyldenløves Fjord, which are up to $965 \mathrm{~m}$ deep, form a discontinuous marginal channel. Notable small accumulations of recent clays appear to be present on the shelf.

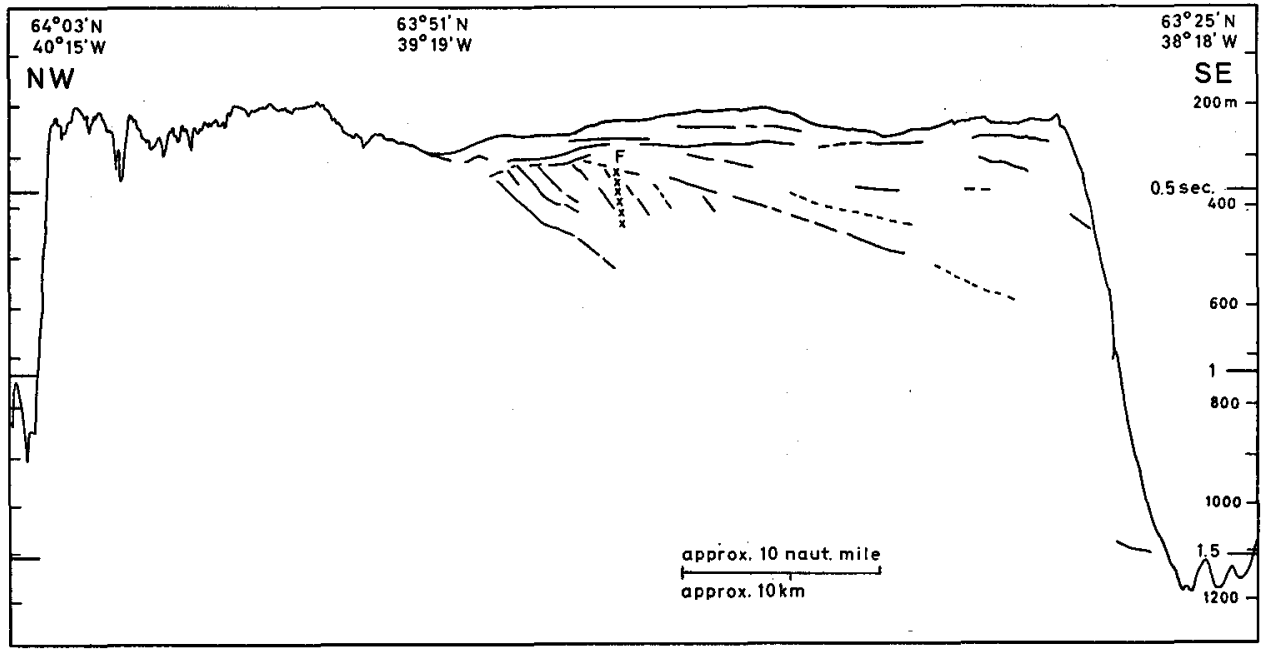

Fig. 19. Seismic profile of the East Greenland shelf at $63^{\circ} 40^{\prime} \mathrm{N}$. The metre scale is corrected for water depth according to Matthews (1939); the time scale is two-way travel time in seconds. The steep escarpment towards the north-west is the edge of the marginal channel (Gyldenløves channel). The upper unconformity is not a regional structure. $F=$ fault. The interpretation is only preliminary. 
The nine seismic cross-sections obtained show that the general structure of the shelf is rather uniform. An example is shown in fig. 19.

The irregular topography of the inner shelf is associated with rather sharp magnetic anomalies, with amplitudes of up to several hundred gammas, and no subbottom reflectors have been detected. It is therefore interpreted as an ice-eroded basement (Vogt, 1970). Roughly $80 \mathrm{~km}$ from the shelf edge, the basement is concordantly covered by a thick sequence of sediments. The boundary follows approximately a line from $65^{\circ} 30 \mathrm{~N}, 35^{\circ} 20^{\prime} \mathrm{W}$ to $63^{\circ} 30^{\prime} \mathrm{N}, 39^{\circ} 45^{\prime} \mathrm{W}$ and is often located in a broad valley on the sea floor. The concordant sediments have a gentle dip of approximately 1:100 away from the shore. This dip may represent a primary slope. Upwards, the sediments are cut by an erosional unconformity. In places in the northern part of the area adjacent to the basement, the unconformity forms the sea floor. However, normally it is overlain by a 50-500 m thick sequence of sediments which often attain their greatest thickness near the edge of the shelf.

\section{References}

Denham, L. R. 1974: Offshore geology of northern West Greenland $\left(69^{\circ}\right.$ to $\left.75^{\circ} \mathrm{N}\right)$. Rapp. Gronlands geol. Unders. 63, 24 pp.

Matthews, D. J. 1939: Tables of the velocity of sound in pure water and sea water. Hydrogr. Dept., London 139, 70 pp.

Sommerhoff. G. 1973: Formenschatz und morphologische Gliederung des südostgrönländischen Shelfgebietes und Kontinentalabhanges. "Meteor" Forsch.-Ergebnisse C 15, 1-54.

Vogt, P. R. 1970: Magnetized basement outcrops on the south-east Greenland continental shelf. Nature, Lond. 226, 743-744.

Institute for Applied Geology, Technical University of Denmark, Building 204, 2800 Lyngby.

\section{Aeromagnetic investigations in East Greenland}

\section{Hans Christian Larsen}

During 1974, aeromagnetic profiling and mapping were carried out in two different parts of East Greenland (fig. 20). The most southerly area comprised the continental shelf between $63^{\circ} 30^{\prime}$ and $66^{\circ} \mathrm{N}$ (Angmagssalik district), while the northern area covered the sedimentary basin of late Palaeozoic and Mesozoic rocks forming the land surface between $70^{\circ}$ and $74^{\circ} \mathrm{N}$.

In addition to straight magnetic flights, low ground clearance flights were carried out over the land area between $70^{\circ}$ and $76^{\circ} \mathrm{N}$ for purpose of radiometric investigation 